\title{
BUDAYA LOKAL DALAM LIBERALISASI PENDIDIKAN
}

\author{
Ravik Karsidi \\ Universitas Sebelas Maret \\ Email: ravikkarsidi1945@gmail.com
}

\begin{abstract}
Abstrak
Globalisasi telah menguasai hampir setiap bidang kehidupan.Banyak kalangan menyepakati pandangan bahwa globalisasi membawa dampak baiksecara positif ataupun negatif.Di sisi lain, Indonesia sedang mengalami perubahan sosial budaya secara terus-menerus, yang didorong oleh inovasi-inovasi di bidang ilmu pengetahuan dan terbukanya informasi dari berbagai sumber.Gelombang perubahan tersebut dikuasai oleh tingkat teknologi baik soft dan hard technology. Dampaknya, teknologi menghadirkan konsekuensi sosial budaya masingmasing. Era globalisasi melahirkan global culture, padahal kebudayaan barat lebih menjunjung rasionalitas, sedangkan kebudayaan timur cenderung memegang nilai tradisi dan keagamaan. Masalahinimenjadipeluangsekaligus ancaman. Mindset masyarakat tentang pendidikan yang bermutu sebagai piranti filter terhadap pengaruh budaya asing belum terbentuk dengan baik. Terdapatkecenderungan menurunnya penghayatan dan pengamalan nilai-nilai lokal sebagai filter sistem terhadap pengaruh liberalisasi khususnya akibat dampak negatif budaya asing. Tulisan ini berupaya mengkaji tentang peningkatan peranan budaya lokal terhadap pengaruh liberalisasi bidang pendidikan yang dilihat dari konsep implementasi pendidikan, penguatan sekolah sebagai pilar sistem sosial-budaya, upaya peningkatan pendidikan berbasis ICT, penguatan pendidikan akhlak, budi-pekerti, dan mentalitas, danpenguatan pendidikan jati-diri dan kemandirian bangsa berbasis kearifan lokal.
\end{abstract}

Kata kunci: globalisasi, budaya asing, liberalisasi pendidikan

\begin{abstract}
Globalizationhas mastered almost every area of life. Many people agree onan opinion that globalization hasan impacteither positively or negatively. On the other hand, Indonesia is undergoing asocial and cultural change on anongoing basis, driven by innovation sin science and opening of information from various sources. A wave of change is controlled by the level of technology in both soft and hard technology. As results, technology brings socio-cultural consequences of each. Global culture gave birth to the era of globalization and western culture over up hold rationality while theeastern culture stend to hold value sandreligioustraditions. These problems become opportunities and threats. The public mind set a boutquality educationas afilterdeviceto the influence offoreign culturehas notformed properly. There is adown ward trend appreciation and practice oflocal values as afilter systemagainst the effects ofliberalizationin particulardue to thenegativeimpact offoreign culture.This paper seeks to examine about the increased role of local culture against the influence of the liberalization of education as seen from the concept of the implementation of education, strengthening the school as a pillar of socio-cultural system, efforts to improve the education based on ICT, strengthening moral education, manners and character, and mentality, and strengthening education the identity and independence of the nation based on local wisdom.
\end{abstract}

Keywords: globalization, western culture, liberalized education 


\section{Latar Belakang}

Sejak Tahun 1995, Indonesia telah menjadi anggota World Trade Organization (WTO). Akibat dari keikutsertaan menjadi bagian dari WTO maka Indonesia melakukan ratifikasi semua perjanjian-perjanjian perdagangan multilateral. Keberlanjutan dari ratifikasi tersebut, maka Tahun 2005 Negara-negara WTO menandatangani General Agreement on Trade in Service (GATS) yang mengatur liberalisasi perdagangan 12 sektor jasa yang didalamnya mencakup bidang pendidikan tinggi dan pendidikan selama hayat. Menurut Sofian Effendi (2007), ada 4 model penyediaan jasa pendidikan dalam WTO yang mempengaruhi terjadinya liberalisasi pendidikan di Indonesia. Pertama, Cross-Border Supply, yaitu pelayanan pendidikan lintas negara, seperti maraknya penawaran kuliah-kuliah melalui internet (online degree). Kedua, Consumption Abroad, yaitu meningkatnya jumlah peserta didik/mahasiswa untuk belajar di lembaga pendidikan/sekolah di luar negeri. Ketiga, Comercial Presence, yaitu kerjasama dengan pendidikan luar negeri seperti partnership, subsidiary, twinning, double degree,dll. Keempat, Presence of Natural Persons, yaitu keberadaan pengajar asing yang mengajar di lembaga pendidikan lokal suatu negara.

Keempat model tersebut pada akhirnya menciptakan terjadinya globalisasi dan internasionalisasi di bidang pendidikan.Situasi ini tidak dapat dibendung dan dielakkan sebagaimana Ferguson menyebutkan globalisasi sebagai "both a journey and a destination" (Ferguson, 2002: 239). Oleh karena itu, maka yang lebih dibutuhkan oleh bangsa Indonesia adalah upaya yang sungguh-sungguh untuk dapat ikut berperan secara signifikan dalam dinamika global serta proses-proses globalisasi. Hal ini sesuai dengan amanat Pembukaan UUD 1945 yang menyatakan bahwa “.... ikut melaksanakan ketertiban dunia yang berdasarkan kemerdekaan, perdamaian dunia dan keadilan sosial ...”. Oleh karena itu, negara harus ikutserta secara aktif dalam menata kehidupan dunia agar semakin damai.

Potensi besar bangsa Indonesia baik karena luasnya wilayahnya, begitu banyaknya pulau-pulau yang dimiliki, banyak jumlah penduduknya, sejarah masa lampau sangat panjang dan dahsyat juga kekayaan fauna yang sangat beragam dan unik, kekayaan flora yang bukan saja sangat beragam dan unik, termasuk juga nilai-nilai budaya yang beragam dan mengesankan. Dinamika kependudukan di Indonesia sedang mengarah ke Fase Windows of Opportunityyang akan memberikan peluang bonus demografi pada Tahun 2030an apabila dapat dimanfaatkan dengan baik. Fase windows of opportunity itu ditandai dengan angka ketergantungan yang paling rendah dalam perkembangan perubahan komposisi penduduk menurut umur. Dengan catatan, jika dinamika demografi khususnya fertilitas mengikuti tren 
selama 40 tahun terakhir. Kondisi itu juga disertai dengan besarnya jumlah penduduk usia produktif, menurunnya jumlah penduduk usia anak-anak dan jumlah penduduk lansia. Artinya, penduduk produktif menanggung sedikit penduduk tidak produktif. Sebagai contoh, di Indonesia, pada tahun 2000, sekitar 80 juta penduduk usia tidak produktif yang terdiri dari warga lansia dan anak-anak bergantung pada sekitar 157 juta penduduk usia produktif (15-64 tahun).

Selain itu, berdasar pada McKenzy Global Institute (2012), Indonesia pada Tahun 2030 akan menjadi negara ketujuh terbesar dalam pembangunan ekonomi. Hal ini dapat terwujud jikalau Indonesia mampu memanfaatkan jumlah SDM yang berkualitas. Selain itu, pada tahun 2045 diprediksi akan mampu memenangkan percaturan dunia dengan slogan "Menuju Generasi Indonesia Emas". Semua ini menjadikan Indonesia akan diperhitungkan sebagai negara besar di dalam kehidupan bangsa-bangsa di dunia. Hal ini mendorong Indonesia untuk terlibat dan mengambil peran yang signifikan terhadap menyelesaikan dinamika global, tidak saja di bidang ekonomi tetapi juga bidang-bidang yang lain.

Selain hal tersebut, berdasarkan pada hasil kesepakatan dunia, maka pengembangan potensi di Indonesia juga berasal dari sektor budaya yang cukup beragam. Masyarakat Indonesia dikenal memiliki tingkat toleransi tinggi dan memegang prinsip sopan-santun. Masyarakat negara lain yang sedang berkunjung ke Indonesia akan lebih dihormati dan dihargai karena tindakan seperti ini adalah tindakan yang juga berkaitan dengan jati diri bangsa di mata warga dunia yang lain. Masyarakat Indonesia juga patut berbangga dengan banyaknya budaya lokal yang dahulu dihasilkan oleh nenek moyang. Batik, seni tari, seni musik tradisional, kerajinan lokal, candi adalah salah satu wujud kebudayaan selain beragamnya bahasa lokal dan ritual keagamaan di Indonesia. Wujud kebudayaan inilah yang menarik bagi masyarakat negara lain untuk berkunjung dan belajar budaya dari manusia Indonesia. Pada masa orde baru atau sebelumnya, misalnya, banyak warga negara asing yang belajar tentang batik di Solo, Yogyakarta, Cirebon dan Pekalongan. Para intelektual asing juga sangat antusias untuk melakukan penelitian kebudayaan dan sosio-ekonomi masyarakat Indonesia.

Banyak teori sosial yang muncul ke dunia intelektual internasional dari Indonesia. Semisal, teori agama masyarakat Jawa dan involusi pertanian (Geertz, 1983), teori ekonomi dan kebudayaan Madura (Huub De Jonge, 2000), teori kejahatan orde baru (Siegel, 2000), teori historiografi Indonesia (Denys Lombard, 2000), dan lainnya, sehingga banyak 
Indonesianis di negara lain. Begitu uniknya manusia Indonesia, sehingga orang luar pun saling berebut dan beramai-ramai berkunjung ke Indonesia untuk menganalisisnya.

Oleh karena itu, bangsa Indonesia harus ikut mengambil peran secara aktif di dalam kehidupan dunia saat ini sebagai urusan yang komplek dengan semakin pesatnya proses globalisasi di seluruh bidang kehidupan. Banyak kalangan pada umumnya menyepakati pandangan bahwa globalisasi membawa dampak secara positif ataupun negatif. Malgaj (2009, dalam Pawito, 2013), misalnya mengatakan bahwa salah satu dampak negatif dari globalisasi adalah meluasnya perusahaan-perusahaan multinasional (multinational corporation, MNC) yang secara langsung membawa konsekuensi antara lain berupa ukuranukuran (standar) tertentu mengenai barang-barang dan jasa layanan jasa, cara-cara produksi, pola konsumsi, dan akhirnya juga perilaku dan gaya hidup.

Pengaruh pendidikan asing bisa menjadi ancaman bagi pendidikan nasional sehingga liberalisasi pendidikan perlu diperhatikan dan diwaspadai. Dalam kenyataannya akibat globalisasi terjadi interdepedensi yang tidak simetris antara negara maju dan negara berkembang. Globalisasi bisa menjadi ancaman melemahkan kedaulatan nasional dan komunitas nasional. Akibat kurangnya daya saing bangsa akan bisa terlibas oleh kekuatan superpower. Masuknya ideologi trans-nasional bahkan bisa menganggu ketentraman hidup masyarakat di negara-negara berkembang. Demokratisasi, HAM, dan liberalisme dapat menyuburkan individualisme yang bertentangan dengan prinsip-prinsip kebersamaan, kekeluargaan, dan kemapanan sosial budaya lokal. Ketergantungan negara-negara berkembang terhadap negara-negara maju dalam teknologi, modal dan pasar ekspor semakin besar. Serbuan informasi dan multimedia (termasuk internet), jika tidak hati-hati, akan dapat merusak nilai-nilai sosial budaya lokal dan cenderug terjadi westernisasi

Di sisi lain globalisasi juga membawa dampak positif terhadap identitas budaya dimana pada kenyataannya globalisasi seringkali juga tidak menghancurkan sama sekali identitas budaya, tetapi justru menciptakan dan memperluas identitas budaya. Hal demikian dapat terjadi terutama karena nilai-nilai global (dari negara maju) tidak selalu diterima begitu saja oleh masyarakat negara sedang berkembang, tetapi bisa menumbuhkan pemikiran dan sikap-sikap kritis terhadapnya.

Dalam rangka menghadapi globalisasi, maka Indonesia harus menyiapkan strategi pembangunan untuk penguatan peran Indonesia melalui pokok-pokok pemikiran yang lebih bersifat operasional-taktis, yaitu: 
1. Mencari peluang untuk pemanfaatan globalisasi bagi peningkatan kemajuan, kemakmuran, dan kesejahteraan bangsa.

2. Meningkatkan kualitas SDM dan membangun karakter bangsa untuk menghadapi tantangan globalisasi dan kemajuan dunia.

3. Mendorong secara bersama sektor ekonomi dan sosial budaya sebagai peningkatan daya saing bangsa.

4. Membangun kebanggaan berbangsa atas jati diri dan budaya Indonesia sebagai bangsa yang bermartabat "berbasis budaya dan keunggulan lokal".

Di sisi lain, Indonesia sedang mengalami perubahan sosial budaya secara terusmenerus, yang didorong oleh inovasi-inovasi di bidang ilmu pengetahuan dan terbukanya informasi dari berbagai sumber, sehingga terjadi akulturasi antara pola-pola lama dengan pola-pola baru dalam masyarakat yang menghasilkan suatu bentuk pola masyarakat yang berbeda sebelumnya.Gelombang perubahan tersebut dikuasai oleh tingkat teknologi baik soft dan hard technology. Dampaknya, teknologi menghadirkan konsekuensi sosial budaya masing-masing (Alvin Toefler, 2000). Era globalisasi melahirkan global culture, padahal kebudayaan barat lebih menjunjung rasionalitas, sedangkan kebudayaan timur cenderung memegang nilai tradisi dan keagamaan. Kondisi ini patut diwaspadai, jika tidak maka bisa akan menghancurkan kehidupan bangsa.

Ancaman tersebut dapat terjadi karena selama ini belum tersosialisasikan secara luas bahwa pendidikan sebagai bidang usaha yang terbuka bagi penanaman modal asing berdasarkan Keputusan Presiden Nomor 77 Tahun 2001. Mindset masyarakat tentang pendidikan yang bermutu sebagai piranti filter terhadap pengaruh budaya asing belum terbentuk dengan baik. Selain itu, adanya kecenderungan menurunnya penghayatan dan pengamalan nilai-nilai lokal sebagai filter sistem terhadap pengaruh liberalisasi khususnya akibat dampak negatif budaya asing.

Oleh karena itu, tulisan ini berupaya mengkaji tentang peningkatan peranan budaya lokal terhadap pengaruh liberalisasi bidang pendidikan yang dilihat dari (1) konsep implementasi pendidikan (2) penguatan sekolah sebagai pilar sistem sosial-budaya (3) upaya peningkatan pendidikan berbasis ICT,(4) penguatan pendidikan akhlak, budi-pekerti, dan mentalitas, (5) penguatan pendidikan jati-diri dan kemandirian bangsa berbasis kearifan lokal. 


\section{Konsep Implementasi Pendidikan}

Pendidikan adalah sebuah proses penyempurnaan semua individu sebagai peserta didik, baik potensi intelektual atau kognitif, mental, rasa, karsa maupun kesadaran martabat kemanusiaannya. Artinya, pendidikan selalu bertujuan untuk membina kepribadian manusia menjadi lebih 'manusiawi' dan mengembangkan serta mengutuhkan potensi kemanusiaannya yang masih terpendam dengan mengedepankan suasana yang penuh cintakasih, kedamaian dan keadilan serta mengesampingkan perilaku yang menindas serta diskriminatif. (Freire, dalam Murtiningsih, 2004:6-7).

Menurut Kartono (2002:4-9), konsep pendidikan dijelaskan dalam empat konsep yang terimplementasi dalam tujuan pendidikan nasional. Pertama, pendidikan adalah proses yang menempatkan siswa sebagai pribadi yang utuh. Tiga unsur utama yang harus dikembangkan adalah competence, conscience, dan compassion yang memberikan perhatian berimbang pada otak, hati dan tangan. Artinya sangat penting untuk memberikan ruangruang bermain bagi siswa sebagai wujud perhatian terhadap perkembangan kepribadian yang utuh. Pengetahuan atau kompetensi memang mengambil porsi yang paling besar dalam proses pendidikan, meski demikian tidak boleh diabaikan pemberian kesempatan untuk mengasah hati nuraninya.

Kedua, pendidikan memberikan kesempatan kepada siswa untuk belajar demi hidup. Nilai rapor yang tinggi bukan satu-satunya tujuan siswa ketika sekolah. Ruang-ruang kelas adalah sebuah dunia yang tidak berbeda dengan dunia sesungguhnya. Belajar bahasa Indonesia tidak hanya sebatas kosakata dan tata bahasa melainkan belajar tentang masyarakat pemakai bahasa lengkap dengan budaya dan komunikasinya akan bisa jauh lebih menarik dan inilah yang disebut dengan belajar untuk hidup.

Ketiga, pendidikan dalam prosesnya perlu memberikan kesempatan berefleksi kepada siswa atas setiap pengalaman. Proses pendidikan lebih banyak menimbun informasi dan pengetahuan tanpa ada pengendapan. Kiranya secara khusus guru (pendidik) perlu membawa peserta didik untuk dapat mensintesiskan antar pengetahuan atau menemukan manfaat bagi dirinya. Hal ini termasuk berbagai kewajiban yang dibebankan kepada peserta didik seperti penggunaan seragam atau melaksanakan upacara bendera, sehingga esensi dari kewajiban itu dapat dipahami.

Keempat, pendidikan adalah tanggungjawab keluarga dan sekolah. Keluarga adalah sekolah yang pertama dan utama. Untuk itu, perkembangan siswa di sekolah membutuhkan 
dukungan nyata orang tua. Dukungan bukan sebatas pendanaan, tetapi lebih dari itu juga berupa pendampingan atau pembimbingan dengan memberikan perasaan aman dan tenang bagi anak-anaknya akan merupakan modal simbolik bagi anak untuk betah bersekolah. Selama ini, sekolah seolah-olah hanya berisi dengan bentuk "penindasan secara halus" karena kebiasaan orang tua yang hanya memberikan instruksi untuk belajar, belajar dan belajar untuk menjadi ranking tertinggi di kelasnya tanpa peduli dengan kejiwaan anak.

Oleh karena itu, dalam membangun pendidikan perlu mengarahkan generasi muda menjadi "generasi pembelajar" yang tidak mudah terperdaya dengan iming-iming globalisasi yang sarat produk kapitalisme. Yang dimaksud dengan "generasi pembelajar" merujuk pada tanggungjawab setiap manusia untuk melakukan dua hal penting. Pertama, senantiasa berusaha mengenali hakikat diri, potensi, bakat serta berusaha mencari jawaban yang lebih baik tentang beberapa pertanyaan eksistensial. Kedua, generasi pembelajar senantiasa berusaha sekuat tenaga untuk mengaktualisasikan segenap potensi, mengekspresikan dan menyatakan diri dengan sepenuhnya menjadi dirinya sendiri dan menolak untuk dibandingbandingkan dengan segala sesuatu yang bukan dirinya.

Sebagai pembelajar, generasi muda akan semakin tegas dan jelas dalam menghadapi setiap gerak perubahan yang harus disikapi dengan kemandirian. Perubahan dunia yang terus menerus terjadi dalam setiap waktu hendaknya dipahami sebagai bahan pelajaran dalam menentukan sikap sesuai dengan kondisi lokal dan karakter bangsa. Generasi muda harus menyadari bahwa bangsa yang cerdas dan berkarakter adalah ketika masyarakatnya mampu mengungkap kesadaran akan hakikat diri dan kemampuan untuk mengaktualisasikan diri sebagai bagian dari proses pengejawantahan karakter kebangsaan dalam usaha memenangkan dalam persaingan dunia internasional.

\section{Penguatan Sekolah sebagai Sistem Sosial-Budaya}

Saat ini kita banyak terperangkap oleh pemikiran dan kebijakan yang memperlakukan sekolah sebagai lembaga pendidikan semata. Sekarang sudah saatnya kita membuka cakrawala pendidikan kita, sehingga memperlakukan sekolah dan proses pendidikan didalamnya sebagai bagian dari sistem sosial-budaya yang ada di sekitarnya. Dalam buku saya (Karsidi, 2005) tentang Sosiologi Pendidikan disebutkan bahwa terjadi saling keterkaitan dan ketergantungan antara sekolahan, keluarga dan masyarakat dimana pendidikan didalamnya sangat terkait dengan mobilitas sosial dan perubahan sosial di 
masyarakat. Karabel dan Halsey (1979) secara khusus bahkan telah mengelaborasi beberapa pandangan untuk membahas tentang peranan pendidikan dalam reproduksi kebudayaan dan transformasi sosial.

Dalam konstruksi sekolahan sebagai bagian dari pilar sistem sosial-budaya, maka peranan pendidikan di sekolahan sangat vital dalam membentuk identitas kultural bagi bangsa Indonesia. Pawito (2013) mendasarkan pada pandangan Rummens (2001) menyatakan bahwa identitas kultural biasanya dirasakan sangat penting oleh warga masyarakat/bangsa bersangkutan di manapun terutama karena identitas kultural dapat berfungsi, selain sebagai (a) penanda atau pembeda karakter bangsa, juga berfungsi sebagai (b) pengikat kebersamaan (yang mempersatukan segenap warga komunitas), sebagai (c) kekayaan bangsa (warisan budaya yang memberikan semacam roh yang karena itu harus senantiasa dipelihara, dilestarikan dan dikembangkan), dan juga sebagai (d) kekuatan yakni kekuatan penggerak dalam kehidupan dan mencapai tujuan baik secara internal sesama warga komunitas maupun eksternal ketika berinteraksi dengan masyarakat/bangsa lain.

Berdasarkan pada pemikiran diatas, maka misi pendidikan di sekolah (dari tingkat dasar sampai pendidikan tinggi) harus mampu menghasilkan pembentukan identitas budaya (nasional) dan sekaligus pembentukan karakter bangsa yang membedakan dengan bangsa lain. Peranan sekolah sebagai garda pertahanan identitas budaya nasional ini penting mengingat selalu ada pengaruh internal dan eksternal dari perubahan global yang dapat mengubah identitas kultural tersebut. Penelitian Heninghan (2002) di Kanada menunjukkan ancaman nyata terhadap budaya Kanada yang sebenarnya bukan komunikasi transnasional yang sampai tingkat tertentu nampaknya mempenetrasi, dan bukan juga teknologi baru termasuk teknologi media. Namun demikian, usaha paling nyata bagi budaya Kanada sebenarnya adalah kecenderungan penyeragaman (uniformity) budaya yang didesakkan oleh media internasional yang didominasi oleh media Amerika. Kondisitersebut telah membanjiri publik di Kanada dengan berita-berita dan paket hiburan yang bercerita dan bergaya Amerika (Henighan,2002:10).

Belajar dari pengalaman penelitian di Kanada tersebut, maka tepat untuk mengikuti tulisan Pierre Bourdieu (dalam Karabel dan Halsey, 1979) yang meletakkan sekolah sebagai lembaga pendidikan yang bertugas melakukan reproduksi kebudayaan dan reproduksi sosial. Dengan memperhatikan ini, maka kita perlu melihat sekolah dalam kerangka luas sampai tataran kebangsaan dan pengembangan peradaban bangsa melalui peranannya sebagai reproduksi kebudayaan nasional Indonesia. Pertahanan sosial kultural kebangsaan dan 
kewarganegaraan Indonesia secara efektif dapat dilakukan di sekolah-sekolah tingkat dasar, menengah dan tinggi, bila sekolah tidak ingin sekedar diperlakukan sebagai tempat belajar dan mendapatkan ijazah untuk bekal bekerja setelah lulus nanti.

\section{Penguatan Jati diri dan Kemandirian bangsa}

Letak dan kondisi geografis Indonesia secara obyektif (berupa kepulauan dan terletak di antara persilangan Benua Asia dan Australia) memungkinkan warga bangsa ini untuk senantiasa terbuka dalam berhubungan dengan warga bangsa lain dengan latar belakang budaya yang berbeda. Kecenderungan seperti ini mengkondisikan berkembangnya internasionalisasi, akulturasi, assimilasi budaya sehingga tercipta apa yang sering disebut dengan budaya Indonesia. Namun demikian sebagai suatu entitas, maka nilai-nilai budaya tidak ada yang mandeg (statis), setidaknya sampai tingkat tertentu namun cenderung bergerak, berubah, dan berkembang secara dinamis. Pertanyaan yang muncul kemudian adalah bagaimana mengupayakan rekayasa dan rancang-bangun untuk pengembangan nilainilai budaya yang dapat memperkokoh jati-diri bangsa dan sekaligus juga memperkokoh kemandirian bangsa.

Para bapak bangsa seperti Soekarno - Presiden pertama RI misalnya, berpesan wantiwanti agar untuk menjawab persoalan bangsa terkait dengan upaya kemandirian, maka terdapat tiga aspek investasi pokok yang harus dikembangkan: (a) mendorong peningkatan investasi modal anak bangsa (invesment of national capital), (b) mendorong peningkatan investasi sumberdaya manusia terutama dalam keahlian teknis dan manajerial (human investment in technical and managerial skills), dan (c) investasi mentalitas anak bangsa untuk mencapai cita-cita bangsa (Abdulgani, 1973:36-37). Dalam ungkapan lain Soekarno merumuskan Trisakti untuk "jalannya revolusi" (yang notabene adalah pembangunan bangsa) yakni meliputi (a) kedaulatan secara politis bagi bangsa Indonesia, (b) mandiri secara ekonomi, dan (c) berkepribadian dalam [ber]budaya (Moch. Said, t.t).

Apa yang dikemukakan di atas dapat dijadikan pilar bagi penguatan pendidikan untuk jati-diri dan kepribadian bangsa. Secara lebih konkrit, maka upaya-upaya yang bisa kita lakukan adalah identifikasi dan sosialisasi nilai-nilai keutamaan yang ada dan dikukuhi oleh bangsa Indonesia dan yang dapat mengantar (compatible) dengan upaya mencapai cita-cita bangsa seperti misalnya kerukunan, gotong-royong, keramahan, kejujuran, keberanian, dan keuletan. Dalam bentuk artefak yang merupakan jejak kemajuan bangsa (mencerminkan 
identitas budaya gotong-royong, suka bekerja keras, dan kerukunan) misalnya adalah Candi Borobudur, dan Candi Prambanan. Kemudian dalam bentuk non-artefak misalnya berbentuk tari dapat dijumpai misalnya Tari Saman (Aceh), Tari Bedoyo Ketawang (Jawa), dan Tari Patenun (Makassar). Dalam hal ini, maka anak bangsa ini sangat membutuhkan dibimbing melalui layanan pendidikan untuk bisa "mengembangkan kemampuan adaptasi" agar bisa menghadapi segala tantangan yang akan terjadi, sehingga bisa berdaya saing tinggi dan percaya diri dalam pergaulan dunia.

\section{Upaya Peningkatan Mutu Pendidikan Berbasis ICT}

Akibat perkembangan teknologi informasi dan komunikasi (TIK) akan mengubah pola hubungan guru-murid, teknologi instruksional dan sistem pendidikan secara keseluruhan. Perlu profesionalisme guru dan kompetensi dalam penguasaan teknologi informasi dan komunikasi. Ilmu pengetahuan dan teknologi (Iptek) merupakan aspek yang paling spektakuler dalam kebudayaan yang karenanya pantas ditempatkan pada kedudukan yang utama dalam pembangunan bangsa. Karena ini, maka pendidikan sains dan teknologi menjadi penyangga sekaligus penyedia kemajuan iptek. Kesadaran ini harus dijadikan titik balik bagi Indonesia yang di masa lampau mengalami sejarah kurang menguntungkan dalam pengembangan tekhnologi sehingga berdampak lemahnya kegairahan bangsa Indonesia dalam pengembangan sain dan teknologi.

Ricklefs (2005) menyebut masa itu sebagai masa "gelap" sejarah Nusantara, dimana kemajuan ilmu dan teknologi yang menghasilkan karya-karya besar yang tidak pernah ditulis dan dibukukan mengakibatkan terputusnya sejarah kejayaan peradaban. Faktanya kita memang kehilangan banyak catatan tentang konstruksi candi Borobudur, teknik penempaan besi-logam untuk pusaka, industri perkapalan yang dapat menyeberangi samudra, serta ilmu pemerintahan dan strategi peperangan yang menghasilkan negara besar nusantara seperti Majapahit dan karya sastra serta seni wayang beserta tari yang sampai sekarang bisa dinikmati. Hal ini diperkuat dalam bukunya tentang Sejarah Modern Indonesia itu, Ricklefs (2005) menyatakan bahwa analisis sejarah baru bisa dimulai pada masa Islam, karena buktibukti historisnya sudah lebih lengkap. Ketiadaan tradisi menulis dan absennya transmisi pengetahuan melalui pendidikanlah yang menyebabkan budaya adi luhung Nusantara tenggelam, bahkan sebagian menjadi sekedar mitos yang berkembang di tengah masyarakat. Maka salah satu saran yang paling penting dalam mengembangkan pendidikan di Indonesia 
tidak lain adalah meningkatkan "budaya menulis" dari tingkat pendidikan paling dasar. Pendidikan seharusnya harus lebih mendorong budaya menulis pada peserta didik melalui peningkatkan apresiasi terhadap ilmu pengetahuan dan alam sekitar melalui tulisan.

Berbasis pada apresiasi melalui budaya menulis tentang alam dan kehidupan di sekitarnya, maka perkembangan sain dan teknologi akan dapat dipastikan keberlanjutannya. Pertanyaan penting adalah: ke arah mana pendidikan sains dan teknologi dikembangkan? Jawaban yang tepat untuk pertanyaan demikian, menurut hemat kami, adalah bahwa pendidikan sains dan teknologi harus dikembangkan untuk mendukung pengembangan industri strategis di Indonesia. Perihal industri strategis seperti apa yang dikembangkan Indonesia, maka hal ini pasti dapat mengalami perubahanlpergeseran dari satu periode pencanangan pembangunan ke periode pencanangan pembangunan yang berikutnya yang bertumpu pada prinsip pembangunan berkelanjutan.

Sudah tentu diskusi publik yang luas dapat saja terjadi berkenaan dengan aspek-aspek apa saja yang akan dipilih untuk dikembangkan oleh bangsa Indonesia sebagai prioritas pengembangan industri strategis. Namun demikian strategi pembangunan di bidang pendidikan dan kebudayaan selayaknya memiliki arah yang jelas untuk mendukung pengembangan industri strategis yang telah dirumuskan sebelumnya. Dari sisi ini, maka nampak urgensi penguatan pendidikan sains dan teknologi demi mendukung pengembangan industri strategis. Untuk konteks Indonesia, maka aspek apapun yang akan dipilih untuk dikembangkan sebagai prioritas industri strategis, maka selayaknya didasarkan pada (setidaknya) tiga prinsip pokok: (1) ketersediaan secara berkelanjutan (di Indonesia sendiri) bahan-bahan yang dibutuhkan, (2) ditujukan untuk kepentingan-kepentingan yang riil dan mendesak bagi bangsa Indonesia, dan (3) kerjasama dengan pihak luar, kalau memang dibutuhkan, secara sederajat dan adil (Karsidi, 2013).

\section{Penguatan Pendidikan Akhlak, Budi Pekerti dan Mentalitas}

Bangsa Indonesia dikaruniai oleh Sang Pencipta dengan berbagai keindahan dan keunikan alam mulai dari bibir pantai yang bukan main eksotis, danau dan gunung yang menawan, hutan dan ngarai yang mempesona, dan juga yang tak kalah penting adalah hasil bumi-laut serta kandungan bumi yang mentakjubkan. Apabila karunia ini ditempatkan sebagai sesuatu yang harus disyukuri dan sekaligus pula sebagai amanah yang harus dipikul dengan penuh tanggungjawab, maka pendidikan akhlak, budi-pekerti, dan mentalitas 
merupakan jalan terbaik untuk kepentingan itu. Penguatan untuk pendidikan akhlak, budipekerti, dan mentalitas, karena itu, harus menjadi bagian penting dari strategi pembangunan pendidikan dan kebudayaan.

Kalau nilai-nilai akhlak dan keadaban boleh dikatakan bersumber dari nilai-nilai agama, maka universalitas nilai-nilai (dalam) agama perlu memperoleh penonjolan untuk upaya di atas. Nilai luhur yang masuk dalam perlu masuk dalam pendidikan akhlak dan keadaban diantaranya adalah mencintai-mengasihi sesama, menerima-menghargai perbedaan, keharusan untuk senantiasa berbuat kebaikan (kepada sesama manusia, kepada alam, dan kepada Sang Pencipta), menjaga-merawat-melestarikan alam, mencintai negeri (sebagai bagian dari iman). Berbagai kata bijak (mengandung nilai-nilai keutamaan) seperti jangan mengambil bukan hak, jangan menyakiti [hati] orang lain, kalau tidak/belum bisa memberi (sesuatu kemanfaatan kepada negara atau kepada orang lain), maka asal jangan meminta, jangan tanyakan apa yang telah negara perbuat untukmu tetapi bertanyalah apa yang telah kau perbuat untuk negerimu dan seterusnya sepatutnya lebih dikedepankan lagi. Strategi penanaman nilai-nilai seperti di atas dapat dilakukan melalui bacaan peserta didik, dan berbagai forum yang bersifat longgar non-kurikuler.

Namun demikian, perlu diperhatikan dalam penanaman nilai-nilai akhlak dan keberadaban, bahwa semua upaya-upaya pembangunan pada akhirnya terpulang pada masalah mentalitas, yakni mentalitas setiap pribadi anak bangsa yang kemudian terpadu ke dalam suatu mentalitas kolektif warga bangsa untuk bersama-sama dan bergotong-royong mewujudkan cita-cita bersama yakni suatu bangsa dan masyarakat Indonesia yang besar, maju, dan adil-makmur. Kalau boleh cita-cita seperti ini kita istilahkan sebagai kemajuan bersama bangsa Indonesia (karena cita-cita harus diupayakan secara sungguh-sungguh dan berkelanjutan), maka persoalan mentalitas seolah lalu menempati posisi sentral. Singkat kata, tidak ada kemajuan jika tidak ada mentalitas untuk maju. Dari sisi ini lalu kelihatan bahwa segala hambatan untuk setiap upaya pembangunan sebenarnya adalah (juga) masalah mentalitas: korupsi misalnya adalah persoalan mentalitas, mencuri harta/milik negara adalah mentalitas, dan mempertaruhkan nasib bangsa-negara (sambil menyembunyikan hasrat pribadi) adalah juga masalah mentalitas.

Konsep tersebut selaras dengan ajaran Ki Hajar Dewantara yang membedakan konsep pendidikan dengan pengajaran. Pengajaran bersifat memerdekakan manusia dari aspek hidup lahiriah (kemiskinan dan kebodohan). Sedangkan pendidikan lebih memerdekakan manusia dari aspek hidup batin (otonomi berpikir dan mengambil keputusan, 
martabat, mentalitas demokratik). Dalam hal ini ajaran hidup yang berbasis budaya tertuang dalam ajaran Trihayu, Trilogi Kepemimpinan, dan Tripantang (Suryadi, 2004).Pertama, Trihayu terdiri dari mamayu hayuning sarira, mamayu hayuning bangsa, dan mamayu hayuning bawana. Maksudnya, apapun yang diperbuat oleh seseorang itu hendaknya dapat bermanfaat bagi dirinya sendiri, bermanfaat bagi bangsa, dan bermanfaat bagi manusia di dunia pada umumnya. Kalau perbuatan seseorang hanya menguntungkan dirinya saja maka akan terjadi sesuatu yang sangat individualistik.

Kedua, trilogi kepemimpinan yaitu Ing Ngarsa Sung Taladha, Ing Madya Mangun Karsa, dan Tut Wuri Handayani. Maksudnya, ketika berada di depan harus mampu menjadi teladan, ketika berada di tengah-tengah harus mampu membangun semangat, dan ketika berada di belakang harus mampu mendorong orang-orang dan pihak-pihak yang dipimpinya. Ketiga adalah Tripantang yang terdiri dari pantang dan berhati-hati kepada harta, praja dan wanita. Kita dilarang menggunakan harta orang lain secara tidak benar (misal korupsi), menyalakangunakan jabatan (misal kolusi), dan berselingkuh dengan wanita lain (menyeleweng). Ketiga pantangan ini hendaknya tidak dilanggar.

Oleh karena itu, penting untuk menghidupkan kembali local knowledge yang kita miliki sebagai benteng pertahanan masyarakat Indonesia. Upaya ini perlu diwujudkan melalui "tripusat pendidikan" yang seringkali terlupakan. Masyarakat Indonesia saat ini lebih menggantungkan pendidikan pada pendidikan formal di sekolah saja, sehingga seolah-olah tanggungjawab karakter anak hanya pada sekolah. Padahal sekolah bukan segalanya. Sekolah hanya bagian dari sistem pendidikan. Membudayakan kembali tripusat pendidikan dengan berbasis budaya lokal diharapkan akan menjadi upaya pemanfaatan bonus demografi yang kita miliki.

\section{Kesimpulan}

Bertolak dari pemikiran-pemikiran di atas maka untuk mengakhiri paparan ini disampaikan 6 (enam) hal sebagai penutup: Konsekuensi meratifikasi GATS adalah menyepakati liberalisasi perdagangan, salah satunya di sektor pendidikan. Oleh karena itu membutuhkan peran aktif bangsa Indonesia di kancah internasional berdasarkan potensi yang dimiliki Indonesia dan sesuai visi ke depan bangsa Indonesia termasuk berkenaan dengan peningkatan kualitas kehidupan, penguatan karakter dan jati diri bangsa, dukungan untuk penguatan industri strategis, penguatan peran Indonesia dalam dinamika global. 
Membangun strategi pembangunan khususnya sektor pendidikan yang diletakkan di atas dasar filosofi dan kepribadian bangsa yakni Pancasila dan UUD 1945. Kalaupun memang harus diterima prinsip-prinsip keterbukaan (dari pengaruh bangsa dan budaya lain/luar), maka negara harus ikut campur tangan misalnya dengan membuat regulasi yang dapat melindungi anak bangsa termasuk yang berkenaan dengan penguatan jatidiri bangsa misalnya bahasa, kesenian, dan berbagai bentuk produk budaya termasuk film dan tayangan televisi.Mencermati hal-hal tersebut, maka tampak bahwa pendidikan mencakup juga lembaga pendidikan non-formal seperti kurus-kursus ketampilan, dan bahkan juga semua bentuk pranata sosial yang ada di masyarakat yang menjadi pusat pembelajaran-pendidikan (pendidikan informal). Selayaknya disadari bahwa bukan hanya sekolah yang menjadi unsur (agent) transfer pengetahuan dan pengalaman yang kemudian akan bisa membantu tumbuhberkembangnya budaya saja, tetapi juga pranata lain yang ada di masyarakat seperti agama dan nilai lokal lainnya. Pendidikan dalam konteks pembangunan kebudayaan seharusnya tidak sekedar menjadi ruang-ruang belajar-mengajar, tetapi diubah menjadi ruang penumbuhan/pengembangan kebudayaan. Sebagai ruang kebudayaan sepert ini, maka proses belajar mengajar diarahkan untuk menjadikan proses interaksi berkebudayaan yang memungkinkan tejadinya proses komunikasi antar budaya. Dengan demikian lalu menegaskan bahwa sekolah hanyalah salah satu dari tempat belajar yang lain yang ada di sekitarnya. Penyelenggaraan pendidikan di rumah, di pusat-pusat kebudayaan dan teknologi dan seni, serta pusat-pusat bermain dan berekspresi, semuanya mendapatkan alokasi waktu pembelajaran yang diperhitungkan secara keseluruhan dalam penyelenggaraan pendidikan nasional. Strategi pembangunan pendidikan berbasis budaya lokal harus diakselerasikan secara terus menerus, sehingga ada/terjadi keberlanjutan yang dengan itu rakyat benar-benar akan merasakan manfaat untuk peningkatan kualitas hidupnya. Oleh karena itu, maka praktek pendidikan seharusnya dilakukan dengan mengutamakan interaksi dan apresiasi kemanusiaan antar peserta didik, guru/dosen dan lingkungan sosialnya sehingga dapat disemaikan akhlak, sikap, mentalitas dan perilaku luhur. Beberapa persoalan nampaknya belum memperoleh pembahasan intensif dalam pra-saran ini termasuk misalnya masalah penganggaran. Kajian di kesempatan lain khusus mengenai hal ini nampaknya sangat dibutuhkan. Semoga cita cita kita mewujudkan bangsa yang cerdas kehidupannya dapat terwujud. Aamiin YRA....*** 


\section{Referensi}

Abdulgani. Roeslan. 1973. Nationalism, Revolution and Guided Democracy in Indonesia, Centre of Southeast Asian Studies, Monash University.

Denys Lombard. 2000. Nusa Silang Jawa (buku 1, 2, \& 3), Jakarta, Gramedia Pustaka Utama Ferguson, Marjorie. 2002, "The Mythology About Globalization” dalam Denis McQuail. Mc Quails'Reader in Mass Communicatioan Theory. London : Sage Publications.

Geertz, Clifford. 1980, Involusi Pertanian, Jakarta, Yayasan Obor Indonesia

Henighan, Tom. 2002. The Media, Globalization, and the Problem and Nationa Identity. (diakses 11 April 2009).

Huub De Jonge. 2012. Garama, Kekerasan dan Aduan Sapi: Esai-esai tentang Orang Madura dan Kebudayaan Madura, Yogyakarta, LKiS

Karabel Jerome and Halsey (ed), A.H, 1979. Power And Idology in Education, New York, Oxfor University Press,

Kartono. (2002). Menebus Pendidikan Yang Tergadai. Yogyakarta. Galang Press

Pawito dan Drajat Tri Kartono, 2013, Identitas Kultural, Komunikasi, dan Globalisasi: Konstruksi Kultural Masyarakat Pluralis dalam Terpaan Globalisasi, Laporan Penelitian, Surakarta, Universitas Sebelas Maret.

Karsidi, Ravik, 2005, Sosiologi Pendidikan, Surakarta, UNS Press.

-------, 2012, “TantanganNasionalKontemporerdanTanggungJawabPerguruanTinggi:, Paper, Konferensi Guru Besarke IV, Makasar.

-------, 2013, MembangunStrategi Pembangunan BidangPendidikandanKebudayaan, BeberapaPokokPemikiran, disampaikandalamKongres HIPIIS, Solo, 13 Oktober 2013.

McKenzy Global Institute. 2012, The Archipelago Economy: Unleasing Indonesian's Potential, McKenzy \& Company, September 2012

Murtiningsih, Siti. 2004,Pendidikan Alat Perlawanan Teori Pendidikan Radikal Paulo Fraire. Yogyakarta. Insist Press

Ricklefs, MC. 2005 . Sejarah Indonesia Modern 1200-2004. Jakarta: Serambi.

Rummens. J. Anneke, 2001. An Interdisiplinary Overview of Canadian Research on Identity, Paper, Halifac, Novascotia. 
Siegel, James T. 2000, Penjahat Gaya (Orde) Baru: Eksplorasi Politik dan Kriminalitas, Yogyakarta, LKiS

Sofian Effendi, 2007. Menghadapi Liberalisasi Pendidikan Tinggi https://groups.yahoo.com/neo/groups/TL_UII/conversations/messages/505, diakses tanggal 3 Mei 2014 jam 19.00

Soekarno, "Lahirnja Panca Sila" dalam Moch. Said (ed.). (t.t.). Pedoman Untuk melaksanakan Amanat Penderitaan Rakjat (Jilid 1). Surabaya: Penerbit Permata.

Suryadi,Asip. 2009. Ajaran Ki Hajar Dewantara: Butiran Mutiara yang Hilang,

Medik Volume 1 Januari - April.

Toefler, Alvin. 2000, The Third Wave, The Clasic Study of Tomorrow, Bantams Book, New York.

Undang-Undang Dasar Republik Indonesia 1945. 